УДК 37.016:821.161.2:7.046

DOI: 10.37026/2520-6427-2020-101-1-70-73
Юлія СИДОРЕНКО,

аспірантка кафедри української літератури,

методики ї̈ навчання та журналістики

Ніжсинського державного університету імені М. Гоголя

\title{
ВИВЧЕННЯ ВЗАЕМОЗВ'ЯЗКІВ МІЖ ПЕРСОНАЖАМИ У ТВОРАХ ІЗ МІФОЛОГІЧНОЮ ОБРАЗНІСТЮ НА УРОКАХ УКРӒ̈НСЬКОЇ ЛІТЕРАТУРИ
}

Стаття присвячена питанню вивчення системних зв'язків між головними персонажами та міфологічними образами як важливого елемента в прочесі шкільного аналізу художніх творів. Представлено етапи навчальної діяльності в процесі вивчення взаємодії між персонажами. Описано спещіально адаптовані види пообразного аналізу, як-от аналіз персонажа за розвитком сюжету, осмислення внутрішніх пріоритетів персонажів, дослідження взаємозв 'язків між міфологічними образами-персонажами. Основну увагу закиентовано на програмових $(9-11$ класи) художніх творах: "Тіні забутих предків» М. Кочюбинського, «Лісова пісня» Лесі Українки, «Енеїда» I. Котляревського, "Дім на горі» В. Шевчука.

Ключові слова: міфологічні персонажі, взаємозв'язок персонажів, пообразний аналіз, методична модель, міфологічна образність.

Статья посвящена вопросу изучения системных связей между главными персонажами и мифологическими образами как важного элемента в процессе школьного анализа художественных произведений. Представлены этапь учебной деятельности в проиессе изучения взаимодействия между персонажами. Описаны специиально адаптированные виды пообразного анализа, например, анализ персонажа с развитием сюжета, осмысление внутренних приоритетов персонажей, исследования взаимосвязей между мифологическими образами-персонажами. Основное внимание акиентировано на программных $(9-11$ классы) художественных произведениях: «Тени забытых предков» М. Кочююинского, «Лесная песня» Леси Украинки, «Энеида» И. Котляревского, "Дом на горе» В. Шевчука.

Ключевые слова: мифологические персонажи, взаимосвязь персонажей, пообразний анализ, методическая модель, мифологическая образность.

The article is concerned with the study of systemic connections between the main characters and mythological figures and creatures. It is an important element in the process of school analysis of literary works. The author theoretically justifies the urgency for the development of a special methodical model of analysing the interrelations among characters of the literary works with mythological imagery. It is appropriate to use the proposed approach in the process of understanding the plot and the system of characters of the literary work.
In particular, interrelations among characters allow us to characterise characters of literary works more completely, to reveal their worldviews, peculiarities of inward choice, spiritual priorities, interaction with external reality, and circumstances of existence.

The article describes the stages of educational activity in the process of studying the interrelations among characters. Different methods and types of activities to be used at lessons are offered at each stage. Specifically adapted type of character-based analysis known in methodology are presented: character analysis by plot development, comprehension of internal priorities of characters, investigation of interrelations among mythological characters. The article describes in detail the scheme of each type of analysis, its purpose and expected results of practical application. The author also gives examples of practical application of the proposed methodical approach. Attention is focused on literary works studied in grades 9-11: "Shadows of Forgotten Ancestors» by Mykhailo Kotsiubynsky, «Forest Son» by Lesya Ukrainka, "Eneyida» by Ivan Kotliarevsky and "A House on a Mountain» by Valeriy Shevchuk. The author provides the examples of analysis of the characters from the mentioned literary works whose evolution depends on the interaction with mythologized reality.

Key words: mythological figures, interrelations among characters, character-based analysis, methodical model, mythological imagery.

Постановка проблеми. Особливістю більшості творів 3 експліцитно представленою міфологічною образністю $\epsilon$ наявність системних зв'язків між головними персонажами та міфологічними образами, істотами. Така взаємодія між персонажами виконує не лише сюжетотворчу роль, а й служить засобом характеристики вчинків та поведінки героїв, пояснення їхніх світоглядних позицій та ціннісних пріоритетів. Такі функції актуалізовані в програмових текстах 3 української літератури для 9 - 11-х класів: «Енеїда» Івана Котляревського (Еней та античні боги, душі померлих), «Лісова пісня» Лесі Українки (Лукаш та його сім'я, дядько Лев і мешканці лісу, озера), «Тіні забутих предків» Михайла Коцюбинського (Іван та гірські, лісові міфологічні істоти), «Дім на горі» Валерія Шевчука (жінки роду та чоловік-птах). Вивчення таких взаємозв'язків між персонажами вважаємо ключовим елементом у процесі шкільного аналізу художніх творів. 
Аналіз наукових досліджень і публікацій. Зауважимо, що в методиці навчання літератури означена вище проблема не лише належним чином не досліджена, а й не напрацьовано певних підходів до іiі розв'язання. Науковці передусім зосереджують увагу на вивченні образів-персонажів, що постають як людина чи літературний герой (Б. Степанишин [8], Є. Пасічник [6], О. Забарний [2], А. Ситченко [7]), рідше - на розгляді міфологічних образів чи персоніфікованих явищ дійсності (Ю. Бондаренко [1], I. Орищенко [5]). Міфологічні образи найчастіше стають об'єктом вивчення спеціальних факультативних курсів (Н. Логвиненко [4]).

Мета статті - теоретично обгрунтувати та розробити методичну модель опрацювання взаємодії між персонажами та міфологічними образами на уроках української літератури у старших класах.

Для досягнення поставленої мети нами було визначено такі завдання:

- окреслити поетапність навчальної діяльності у процесі вивчення взаємодії між персонажами;

- адаптувати різні види пообразного аналізу до роботи з творами міфологічного змісту на уроках літератури;

- доповнити запропонований методичний підхід практичними розробками.

Виклад основного матеріалу. Персонажі, що взаємодіють із міфологічними істотами, зазвичай належать до динамічного типу. Зміни їх характеру залежать від взаємодії з міфологізованою реальністю. Наприклад, у драмі-феєрії Лесі Українки «Лісова пісня» Лукаш по-різному поводиться з Мавкою, матір'ю та Килиною. Дослідження еволюції образу доцільно здійснювати, аналізуючи та зіставляючи сюжетні точки, в яких герой виявляє риси своєї натури під час спілкування з міфічними лісовими мешканцями та ріднею. У повісті «Тіні забутих предків» М. Коцюбинського життя головного героя Івана від народження до смерті наповнене міфологічним змістом, тобто його «доля (міфологічна категорія) обумовлена язичницьким світоглядом, у якому давні українці долями іноді називали душі предків, владою в ньому ритуалів» [3, с. 118]. На зміни внутрішнього світу Івана впливає його взаємодія із щезником, мольфаром, чугайстром, нявкою. У поемі «Енеїда» I. Котляревського важливі події в житті Енея залежать від участі в них олімпійських богів та героїв. Наведені приклади вказують на необхідність розгляду взаємин із міфологічними істотами в процесі аналізу образів-персонажів як провідного чинника, що зумовлює внутрішні протиріччя та динаміку розвитку героїв твору.

Навчальна діяльність учнів із вивчення взаємозв'язків між персонажами та міфологічними істотами відбувається поетапно:

I. Сприймання. Учні читають твір, виконуючи випереджувальне завдання: виділяють епізоди, в яких герої взаємодіють із міфологічними істотами, 3'ясовують значення невідомих міфологічних назв.

II. Характеристика світогляду, вчинків, поведінки та особистісних рис персонажів-людей. На цьому етапі вчитель використовує один із запропонованих різновидів пообразного аналізу, доречний для конкретного твору та можливостей учнівського колективу:

1. Аналіз персонажа за розвитком сюжету. Цей варіант роботи досить детально описаний у посібнику Ю. Бондаренка [1], де науковець подає цілісну версію послідовного аналізу персонажів у їх сюжетно-композиційній динаміці. Для поглибленого вивчення пропонуємо епізоди, «які мають принципове значення для розуміння сутності героя, логіки його характеру і разом з учнями проводить їх дослідження, виявляючи ті риси образу, які там змальовані, а також роль художніх засобів у їх втіленні» [1, с. 110]. Однак дана методика не спрямована на вивчення взаємозв'язків між міфологічними персонажами. Зважаючи на специфіку аналізу персонажа за розвитком сюжету та характеротворчу значимість контактів між образами, слід пристосувати цей вид аналізу до опрацювання головних героїв творів 3 експліцитним міфологізмом. Зокрема, акцентувати увагу на таких сюжетних точках, де відбувається взаємодія саме 3 міфологічними образами. Наприклад, для характеристики Лукаша 3 драми-феєрії Лесі Українки «Лісова пісня» обираємо епізоди: знайомство з Мавкою; Мавка й Килина на полі; перетворення у вовкулаку; зустріч із Долею; гра на вербовій сопілці. Опорними точками, що розкривають характер Івана з повісті М. Коцюбинського «Тіні забутих предків», є такі епізоди: зустріч зі щезником; танець із чугайстром; нявка веде до прірви.

У такому разі пообразний шлях аналізу переплітатиметься з подієвим, що цілком вмотивовано логікою дослідницької роботи з текстом твору. Обираючи аналіз персонажа за розвитком сюжету, дотримуємося такої стратегії:

- знаходимо сюжетні точки, в яких персонаж-людина, взаємодіючи $з$ міфічними істотами, розкриває свій характер, світосприйняття, особливості внутрішнього світу;

- характеризуємо, яку роль міфологічний образ виконує для розкриття сутності людини;

- встановлюємо, як міфологічна образність впливає на розкриття, розвиток чи зміни характеру персонажа-людини.

Послідовне опрацювання епізодів вибудовує логічний ланцюжок змін у внутрішньому світі та поведінці героїв, вказує на домінантні риси їх світобачення та розкриває систему цінностей.

Покажемо це на конкретному прикладі. Опрацювання епізодів взаємодії Лукаша й Мавки в «Лісовій пісні» Лесі Українки сконцентровуємо над такими питаннями:

1) Перша зустріч Мавки та Лукаша:

- Опишіть, яким перед Мавкою постає Лукаш.

- Що Лукаш говорить про свої найближчі плани? Чи має він конкретну життєву мету?

- Як герой реагує на роздуми Мавки про буття й кохання? Чи проявляються тут риси його вдачі, світогляду?

2) Прогулянка нічним лісом:

- Як Лукаш ставиться до Мавки, як виражає свої почуття? На які риси характеру вказує його поведінка?

- Як ви розумієте слова Мавки «У тебе голос чистий, як струмок,/ а очі - непрозорі»?

- Які думки та цінності домінують у душі Лукаша під час спілкування з Мавкою?

3) Лукаш і Мавка на житньому полі.

- Прочитайте діалог двох героїв, розкрийте його зміст.

- Між якими цінностями Лукашу доводиться робити вибір?

- Зачитайте слова-реакцію Лукаша на зблідлу Мавку. 
- Як зміна ставлення до Мавки змінює самого героя? Які риси його характеру тут виражені?

- Доведіть, що в Лукаша змінюються життєві пріоритети.

4) Лукаш після переродження з вовкулаки грає на сопілиі:

- Як ви розумієте слова Лукаша «Я, жінко, бачу те, щчо ти не бачиш.../ Тепер я мудрий став...»?

- Як переоцінив своє життя Лукаш? Як любов Мавки вплинула на світобачення героя?

5) Лукаш і Доля:

- Що, на вашу думку, зрозумів Лукаш після розмови 3 Долею?

- Яким постає перед нами герой у кінці твору?

Узагальнення школярі роблять, відповідаючи на проблемні запитання:

- Завдяки яким міфологічним істотам Лукаш шукав і знайшов власні життєві орієнтири?

- Як Мавка вплинула на становлення особистості Лукаша?

- Чи зміг би герой вирішити конфлікт між прагматизмом і духовністю без взаємодії $з$ лісовими мешканцями? Чому?

2. Осмислення внутрішніх пріоритетів персонажів. Аналіз взаємодії з міфологічними істотами допомагає здійснити характеристику образів-персонажів, зокрема виявити їхнє ставлення до навколишньої дійсності, світосприйняття. Дослідження системи цінностей персонажа включає такі етапи:

- визначення особливостей сприйняття героєм міфологічних явищ, ставлення персонажа до надприродних сил, взаємодії з ними;

- осмислення ціннісного конфлікту між реальним і міфологічним світами;

- встановлення життєвої мети героя (зокрема, наскільки вона пов'язана з міфомисленням).

Наприклад, у житті Івана та Палагни (повість «Тіні забутих предків» М. Коцюбинського) вагоме місце займають міфологічні вірування, відповідно до яких герої упорядковують свій щоденний ритм життя. Залежно від ставлення персонажів до міфологізованих явищ природи, дотримання народних обрядів та звичаїв можемо визначити їхні життєві цінності. Учитель пропонує для обговорення епізоди, в яких взаємодія героїв із міфологізованою реальність розкриває їхні світосприйняття та пояснює вдачу й поведінку. План аналізу включає дослідження епізодів, в яких зображено: уявлення малого Івана про світ; зустріч Івана зі щезником; взаємини Івана та Палагни із сусідами; поведінку подружжя у Святий вечір; ворожіння Палагни на Юріїв день; боротьбу мольфара Юри 3 хмарою; замовляння глиняної ляльки з метою вбити Івана; танець Івана із чугайстром; падіння Івана в прірву, роль нявки в цьому; похорони, голосіння Палагни.

Зважаючи на брак часу на уроці, старшокласникам доречно буде дослідити кожен епізод у парах, а результати роботи представити для класу у формі відповідей на запитання:

- Які життєві цінності персонажів виявляються в стосунках із міфологічними істотами?

- Чи відрізняються стосунки героїв із міфологічними істотами та реальними людьми? На який внутрішній конфлікт це вказує?

- Як міфомислення персонажів впливає на їхнє життя?
Запропонована самостійна групова робота учнів активізує їхні мисленнєві дії та вдосконалює навички систематизувати й узагальнювати досліджений матеріал, адже «без самостійної роботи учнів залишаються голе викладання і сама видимість навчання» [8, с. 70].

3. Дослідження зв'язків між міфологічними образами-персонажсам. Взаємодію персонажів визначити досить легко, адже вона передбачає їх спільну участь у певних змістових фрагментах. Її аналіз передбачає виокремлення героїв, які контактують між собою, оцінку їх внутрішніх якостей, виражених у процесі взаємодії [1, с. 183]. Набагато важче - дослідити функціональну систематику, тобто визначити функції персонажів у реалізації поставлених письменником художніх завдань. Зважаючи на це, образи можуть ділитися на протилежні між собою групи (наприклад, небезпечні для людини та корисні у «Тінях забутих предків» М. Коцюбинського), мати символічне універсальне значення, співвідноситися 3 певним типом людей чи нацією (троянці - українці в «Енеїді» I. Котляревського). Учні повинні вміти групувати персонажів, визначати їхню спільну роль у тексті, здійснювати порівняльну характеристику, а також зіставляти персонажів одного чи кількох творів.

Наприклад, олімпійські боги та троянці в поемі I. Котляревського «Енеїда» зображають контрастні типи суспільних класів українського суспільства: панство, вельмож та народні маси. У тексті чимало епізодів, у яких вони взаємодіють як всередині своїх груп (боги з богами), так і сцен міжгрупової взаємодії. Доречно виокремити та порівняти стосунки персонажів у таких фрагментах із метою проникнення в проблемно-тематичне поле поеми. Цікавими для розгляду, на нашу думку, можуть бути такі епізоди: «змова Юнони 3 Еолом» - «суперечка олімпійських богів» - «Еней у пеклі» - «Венера просить Вулкана скувати Енеєві зброю». Обговорення кожного епізоду необхідно завершити визначенням закладеної в нього ідеї: викриття підкупності та хабарництва - висміювання чиновницької сваволі, інтриганства - виявлення найпомітніших вад тогочасного суспільства - показ підлабузництва.

Процес міжгрупової характеристики призведе до осягнення загальної картини зображеної автором тогочасної дійсності. Однак, застерігає Є. Пасічник, «не слід зводити групову характеристику образів до виділення лише загального в них. Групову характеристику необхідно доповнити індивідуальною» [6, с. 274]. Тому додатковою ілюстрацією міжособистісних стосунків персонажів стає визначення основних рис вдачі найпоказовіших героїв кожної групи (Енея, Зевса, Венери).

У «Лісовій nicнi» Лесі Українки група міфологічних персонажів протиставляється групі людей, що й служить основою проблематики драми-феєрії. Ефективним прийомом аналізу системних зв'язків між персонажами тут буде зіставлення світоглядних позицій кожної групи та визначення основ для їх взаємодії. Роботу проводимо, досліджуючи такі питання:

- Як відрізняються погляди лісових, водяних мешканців і людей щодо устрою сімейного життя (знаходимо відповідні висловлювання в діалогах між Водяником і Русалкою, лісовиком і Мавкою, Мавкою та Лукашем про кохання, матір'ю Лукаша і Килиною)?

- Що забезпечувало співіснування протилежних груп персонажів на одній території (розкриваємо зміст угоди дядька Лева, наслідки ії порушення)?

- Як означена взаємодія розкриває головну ідею та проблематику драми-феєрії? 
Аналіз доречно супроводжувати складанням таблиць, що відображають результати дослідно-пошукової роботи учнів із текстом. Наприклад, пропонуємо їм зафіксувати ключові ситуації, де відбувається взаємодія персонажів із міфологічними істотами, та особливості прояву в них характеру героїв. Позитивний ефект має створення асоціативних схем, оцінювальних карток. Наприклад, основою асоціативної схеми чи картки $\epsilon$ пара персонажів (жінка й чоловік-птах до роману-балади «Дім на горі» Валерія Шевчука; Еней i Венера до поеми «Енеїда» I. Котляревського; Лукаш і Мавка до драми-феєрії «Лісова пісня» Лесі Українки; Іван і нявка до повісті «Тіні забутих предків» М. Коцюбинського). Для кожної пари учні здійснюють визначення світогляду, головної риси героя, його думок, почуттів, що оприявлені письменником крізь призму стосунків із міфологічними персонажами.

III. Власна оцінка набутих знань, сформованих умінь та навичок.

Даний етап передбачає узагальнення та систематизацію вивченого матеріалу. Старшокласники підсумовують та висловлюють свої думки щодо зв'язку головних героїв-людей із міфологічними істотами, вплив цієї взаємодії на формування та зміни характеру й поведінки персонажів.

Головними методами та прийомами роботи в процесі запропонованого підходу до вивчення персонажів, що взаємодіють із міфологічними істотами, є:

- читання (вибіркове, коментоване; учні виконують завдання на відтворення змісту епізодів);

- розповідь учителя, в контексті якої відбувається пояснення міфологічних термінів, цитування літературознавчих праць, застосування прийомів наочності;

- бесіда репродуктивного та евристичного характеру (постановка запитань і завдань пізнавального та проблемного характеру);

- дискусія (колективне обговорення проблемного питання).

Висновки. Отже, поглиблене дослідження взаємозв'язків між персонажами-людьми та міфологічними істотами - ефективний спосіб пообразного аналізу творів із експліцитним міфологізмом. Його використання дозволяє дати більш повну характеристику образів-персонажів літературних творів, розкривши їхні світоглядні уявлення, особливості внутрішнього вибору, духовні пріоритети, взаємодію із зовнішньою реальністю, обставини існування тощо.

Сподіваємося, що запропонована методична модель буде корисною не лише для практикуючих учителів-філологів на уроках української літератури в старших класах, а й для студентів філологічних факультетів, внесе своєрідну новизну в розробку системного підходу до вивчення творів із міфологічною образністю.

\section{СПИСОК ВИКОРИСТАНОЇ ЛІТЕРАТУРИ}

1. Бондаренко Ю. І. Вивчення образів-персонажів літературного твору в школі: теорія і практикум: посіб. для студ. філол. ф-тів / Ю. І. Бондаренко. - Ніжин : НДУ ім. М. Гоголя, 2015. - 216 с.

2. Забарний О. В. Психологічна характеристика образу-персонажа: навчально-методичний посібник / О. В. Забарний. - Ніжин, 2015. - 76 с.

3. Кіяновська М. Засоби міфологізації персонажів у повісті М. Коцюбинського «Тіні забутих предків» / М. Кіяновська // Молода нація. - 1997. - № 5. C. 113-119.

4. Логвиненко Н. Вивчення національної автентичної міфології як джерела сучасного українського фентезі / Н. Логвиненко // Українська література в загальноосвітній школі. - 2014. - № 11. - С. 40-46.

5. Орищенко I. М. Вивчення образів стихій природи на основі застосування хронотопного аналізу / I. М. Орищенко // VII Волошинські читання «Шкільна мовно-літературна освіта: традиції і новаторство» : матеріали всеукр. наук.-практ. конф. (Київ, 17 травня 2019 р.). - Київ, 2019. - С. 332-335.

6. Пасічник С. Методика викладання української літератури в середніх навчальних закладах / Є. Пасічник. - Київ, 2000. - 384 с.

7. Ситченко А. Л. Навчально-технологічна концепція літературного аналізу : монографія / А. Л. Ситченко. - Київ : Ленвіт, 2004. - 304 с.

8. Степанишин Б. Викладання української літератури в школі / Б. Степанишин. - Київ, 1995. - 256 с.

Дата надходження до редакиії: 12.12.2019 p. 